\title{
Cowpea Innovation Platform Interventions and Achievements in TL III Project in Burkina Faso
}

\author{
Batieno Benoit Joseph, Poda Saadon Leandre, \\ Barry Silamana, Compaore Evelyne, Zongo Hamadou, \\ Sidibe Hamadou, Gnankambary Karidiatou, \\ Sanou Ouedraogo Adelaide, and Neya B. James
}

\begin{abstract}
In June 2015, four multi-stakeholder platforms (Sanguie, Zondoma, Soum, and Association Yiye) were established in different regions of Burkina Faso to promote agricultural activities. By 2018, more than 200 farmers had already been trained on different aspects of the cowpea value chain including grain production, storage, and food processing skills. The platforms played a key role in the dissemination of new cowpea varieties through demonstrations, field days, the mass media, and social media. About 160 demonstrations were established by the members of the platforms every year from 2015 to 2018 . Each platform was supported to produce 10 ha of certified seeds making a total of 40 ha each year and 160 ha during the four-year period. Due to the demand for foundation seeds that was increasing year after year in Burkina Faso and the inability of INERA to produce enough seeds, the most successful platform members were contracted by the INERA Seed Unit to produce foundation seeds in order to meet the high demand in the country for certified seed production. Although there are no official statistics about certified seeds produced in Burkina Faso in terms of demand, recent happenings have shown their increased production. For instance, in 2018 about 1000 tons of certified seeds were produced compared to previous years which had less than 700 tons.
\end{abstract}

\section{Keywords}

Cowpea $\cdot$ Multi-stakeholder platforms · Burkina Faso · Technology dissemination $\cdot$ Mass media $\cdot$ Social media

B. B. Joseph ( $\square)$ · P. S. Leandre · B. Silamana · C. Evelyne · Z. Hamadou · S. Hamadou ·

G. Karidiatou $\cdot$ S. O. Adelaide $\cdot$ N. B. James

Institut de l'Environnement et de Recherches Agricoles (INERA),

Ouagadougou, Burkina Faso 


\subsection{Introduction}

Cowpea is one of the most important and widely cultivated legumes in the world particularly in Africa (Verdcourt 1970). The development of new varieties in Burkina Faso is basically ensured by INERA, which is a public institution. According to Tignegre (2010) and Batieno (2014), the low adoption rate for new varieties is due to the fact that the end-user preferences were not taken into account during the process of variety development. On the other hand, there is low adoption of the new varieties that were developed after taking the farmers' preferences into account. This arises from farmers' inability to have access to adequate quantities of the new improved varieties owing to poor commercialization networks, lack of performing seed companies, or poor production resulting from inadequate agronomic production packages or post-harvest losses from insect pests and poor storage conditions. Despite the fact that farmers recognize the importance of high-quality seeds, the seed sector in Burkina Faso continues to face numerous problems even with the interventions made by the Government and donors such as BMGF via the Alliance for Green Revolution in Africa (AGRA) or Tropical Legumes (TL III). The uptake of improved varieties by the resource-poor farmers is inhibited by the cost of seeds and by the less than perfect channels of communication between them and the breeders/seed producers. INERA is the mode of acquisition of the new varieties through its demonstration (demo) plots, Government-supported agricultural extension services, and NGOs.

\subsection{Objectives of the Platform}

The platforms were created to constitute a framework for consultation and exchange of experiences around the cowpea value chain. It is an approach that connects all value chain actors in the cowpea industry and all the activities required for the realization of innovation by a group of individuals or representatives of institutions that interact according to rules set by themselves to fulfill a common function. The key objectives are to: (1) increase the capacity to manage and use existing knowledge to innovate, and (2) build individual and/or institutional capacity and integrate cowpea research with other actors in society to produce good quality seed. In this sense the actors cooperate, communicate, interact, and share objectives to collectively support the processes of development while making use of the innovations of a value chain.

\subsection{Establishment of the Platform}

Year of the establishment (for each platform)

Four different platforms were established between 2016 and 2018 in different regions of Burkina Faso. The platform of Sanguie was the first to be established on 24/25 May 2016; it was followed by the platform of Soum on 6/7 June 2016. The platform of Zondoma was set up a few days later on 9/10 June 2016. The Association 
Yiye was the last to be established on 12/13 June 2018. The number of men and women in the platforms grew from year to year (Table 11.1).

\subsection{Overall Process of Platform Establishment}

Innovation platforms were established in a province of the different regions concerned. This implementation was carried out in the presence of producers and processors, members of the Steering Committee, as well as certain provincial officials. A research team is also present during the installation of the various platforms. After being made aware of their different responsibilities the members of the Steering Committee were officially installed by the provincial administrative authorities.

\subsection{Composition, Roles, and Responsibilities of the Platform Members}

The Burkina Faso cowpea platforms are multi-stakeholder in nature, consisting of researchers, seed producers, grain producers, food processors, agro-input dealers, community local authorities, microfinance institutions, and representatives of the Ministry of Agriculture-each of them with defined functions and responsibilities as outlined in Table 11.2.

\subsection{Platform Activities}

The platform activities are planned every year by the governance body. A special review and planning meeting (RPM) will be convened by each governance body under INERA coordination. During this RPM members will present the results of

Table 11.1 Number of members in the platforms from 2015 to 2018

\begin{tabular}{l|l|l|l}
\hline 2015 & 2016 & 2017 & 2018 \\
\hline 264 (m: 200; f: 64) & $558(\mathrm{~m}: 357 ; \mathrm{f:} \mathrm{201)}$ & 888 (m: 616; f: 272) & 968 (m: 580; f: 388) \\
\hline
\end{tabular}

Table 11.2 Roles and responsibilities of different stakeholders participating in platform activities

\begin{tabular}{l|l}
\hline Stakeholders & Roles and responsibilities \\
\hline Researchers & Coordination, technology diffusion, capacity building \\
\hline Seed producers & Make the seeds available for farmers \\
\hline Grain producers & Produce for consumers \\
\hline Agro-dealers & Provide inputs (insecticides, herbicides, and fertilizers) \\
\hline Local authority & Facilitates cohesion between the different actors \\
\hline Microfinance & Facilitates availability of finance to producers \\
\hline Agriculture & Extension agents \\
\hline Food processors & $\begin{array}{l}\text { Transform cowpea into different sub-products (value } \\
\text { addition) }\end{array}$ \\
\hline
\end{tabular}


the past year for demo plots, field days, seed production, and quantity of seeds sold, and quantify the amount of support received from the project. After the review, the activities for the next year will be planned. The members will identify the activities to be conducted, identify training themes, and identify people who should be trained under the topics prioritized. The main challenge is implementation of the many different agreements with partner members, proper use of financial resources from seeds sold to sustain more production, and the absence of a smooth flow between different links in the chain. These challenges served as a justification for developing a Managerial Guide document for all members of the platforms with highlights on training sessions that include implementation of demo plots, production of cowpea seeds, and production of cowpea grain. Best practices for soil fertilization were also taught to the different members of the platforms. The members learned how to identify different diseases on cowpea and how to deal with them. Platforms also facilitated the dissemination of new varieties of cowpea through the implementation of demo farms and also field days. During these field days participants are asked to give their opinion on the different varieties involved, to choose the best varieties, based on their own criteria, and play a key role in giving names to the different varieties that will be released.

The best farmers among the members were chosen to sign contracts with INERA in the production of foundation seeds. We also involved the different platforms in the production of certified and quality declared seeds (QDS).

\subsection{Facilitation of Platform Activities, Including Meetings}

\subsubsection{Description of How the Process Was Led and Which Actor Helped Platform Members to Implement Their Activities}

Each platform has a scientist from INERA who is responsible for technical and financial support where it applies, ensures that all the other activities are executed as planned, and holds discussions with other members of the governance body to prepare meetings and field days and collect information. The local authority helps in facilitation including availability of agricultural inputs while the agricultural extension officers work directly with farmers to ensure that recommended production packages are correctly applied.

\subsubsection{Use of Democratic Tools and Mechanisms to Enhance Stakeholder Participation}

Meetings are planned by the governance body and each member of the value chain will participate and share information with the members of its link in the chain. For example, the stakeholder representing other seed producers will participate and share information with them. 


\subsection{Achievements of the Platform}

The important achievement is the reinforced connection and trust built between extension services and small-scale farmers. Other important achievements facilitated by the platform include specialization of farmers in specific areas such as traders, processors, grain producers, and seed producers. A case study was conducted at Gourcy MSP through two focus group discussions with cowpea farmers, 12 females and 12 males, who have benefited from the project's seed dissemination schemes. A mixed methods research design was used starting with two separate discussion groups, male and female. Key informant interviews were held with two extension agents (one male and one female), two male seed producers, two females and two males from the multi-stakeholder platform, and a random sample survey of 200 respondents from five Gourcy communes. The sample size of 200 respondents was composed of 100 females and 100 males. In each commune 20 female respondents and 200 males were selected for the survey in each commune. The respondents were selected randomly with the help of the extension agents. In addition, a survey study was carried out of 200 respondents made of 100 females and 100 males that have actively participated in the project activities in the MSP. A structured questionnaire was designed for this survey. The questions that were used collected the quantitative data that quantified the qualitative data. The results of the questionnaire surveys were analyzed with SPSS and Stata software by using unpaired t test.

\subsection{Achievements in Access to Improved Cowpea Varieties by Gender}

The survey revealed that an average of $89 \%$ of the respondents have access to improved seeds. The level of access represents $88 \%$ for men and $90 \%$ for women, thus women have more access to improved cowpea seeds than men. This is due to different interventions of the Government, Projects, and NGOs in the area (Table 11.3).

About $80 \%$ of the producers surveyed have access to the improved variety Komcallé. It is also the most cultivated variety in the area where $81 \%$ of women have access to this variety compared to $79 \%$ of men. Access to improved seeds of Tiligré was $42 \%$ overall by men and women.

Table 11.3 Access to improved varieties of cowpea

\begin{tabular}{l|l|l|l}
\hline \multirow{2}{*}{ Do you have access to improved varieties of cowpea? } & Gender & \multirow{2}{*}{ Mean } \\
\cline { 2 - 4 } & Male & Female & (10 \\
\hline Yes & 88 & 90 & 89 \\
\hline No & 12 & 10 & 11 \\
\hline Total & 100 & 100 & 100 \\
\hline
\end{tabular}


Table 11.4 Access to the improved varieties of cowpea Komcallé and Tiligré by gender

\begin{tabular}{l|c|c|l}
\hline \multirow{2}{*}{ Access to improved varieties of cowpea } & \multicolumn{2}{|l|}{ Sex } & \multirow{2}{*}{ Chi square } \\
\cline { 2 - 3 } & Male & Female & 0.2043 NS \\
\hline Yes & 88 & 90 & \\
\hline No & 12 & 10 & \\
\hline Total & 100 & 100 & \\
\hline
\end{tabular}

$N S$ not significant

Table 11.5 Chi square test of the acquisition mode of improved varieties of cowpea

\begin{tabular}{l|c|l|l|l|l|l}
\hline \multirow{2}{*}{$\begin{array}{l}\text { Mode of acquisition to } \\
\text { improved varieties of } \\
\text { cowpea }\end{array}$} & \multicolumn{3}{|l|}{ Komcallé improved seeds } & \multicolumn{3}{l}{ Tiligré improved seeds } \\
\cline { 2 - 4 } & Male & Female & Chi square & Male & Female & Chi square \\
\hline Purchase & 46 & 18 & $28.4018^{* * *}$ & 15 & 3 & $13.6127^{* * *}$ \\
\hline Savings & 2 & 3 & & 0 & 1 & \\
\hline Donations & 12 & 41 & & 17 & 31 & \\
\hline Subsidies & 20 & 23 & & 10 & 7 & \\
\hline
\end{tabular}

${ }^{* * *}$ significant at $1 \%$

The study revealed that there was no significant difference between men and women for access to all four improved varieties. Quantities available are not enough to meet the demand for seeds. Women have more access to improved cowpea seeds than men, though the difference was not significant. One extension agent said, "I received only $1250 \mathrm{~kg}$ of seeds this year (2018) for the whole province of Gourcy and because of that we favoured women during seed distribution." (Table 11.4)

The main modes of acquisition of seeds of improved cowpea variety Komcallé are by purchase $(38.8 \%)$, donations $(32.10 \%)$, and subsidies (26.10\%). Men $(57.50 \%)$ buy more improved varieties than women $(21.20 \%)$. Women receive more donations than men $(48.20 \%$ vs $15 \%)$. Women benefit more from subsidies than men $(27.10 \%$ vs $25 \%)$. The main acquisition methods for seeds of the improved seeds of the Tiligré variety are mainly donation (57.10\%) followed by purchase $(21.40 \%)$ and the grants $(20.20 \%)$. About $73.80 \%$ of the women acquire the variety Tiligré by donation, while $40.50 \%$ of the men acquire it through this channel. $35.70 \%$ of men and $7.10 \%$ of women acquire Tiligré seeds through purchase. Men $(23.80 \%)$ are much more subsidized than women $(16.70 \%)$ for the Tiligré variety.

The Chi square test showed that there is a significant difference between men and women at the $1 \%$ level for Komcallé and Tiligré varieties (Table 11.5).

\subsection{Sources of Seeds for the Improved Varieties Komcallé and Tiligré Disaggregated by Gender}

The Government is the main supplier of seed of the improved variety Komcalle and $62.40 \%$ of producers obtained the Komcallé variety from the Government through the agricultural extension services in the province, while $71.8 \%$ of women obtained Komcallé through this channel compared to $52.50 \%$ for men. The second important 
Table 11.6 Origin of the improved cowpea variety Komcallé and Tiligré by gender in percentages

\begin{tabular}{|c|c|c|c|c|c|c|}
\hline \multirow[b]{3}{*}{ Origin of the variety } & \multicolumn{3}{|c|}{ Variety Komcallé } & \multicolumn{3}{|c|}{ Variety Tiligré } \\
\hline & \multicolumn{2}{|c|}{ Gender } & \multirow[b]{2}{*}{ Mean } & \multicolumn{2}{|l|}{ Gender } & \multirow[b]{2}{*}{ Mean } \\
\hline & Male & Female & & Male & Female & \\
\hline State/government & 52.50 & 71.80 & 62.40 & 46.50 & 23.80 & 35.30 \\
\hline NGO/project & 18.80 & 15.30 & 17.00 & 23.30 & 28.60 & 25.90 \\
\hline INERA/TLIII & 28.80 & 10.60 & 19.40 & 25.60 & 47.60 & 36.50 \\
\hline Savings & & 2.40 & 1.20 & 4.70 & & 2.40 \\
\hline Total & 100 & 100 & 100 & 100.00 & 100.00 & 100.00 \\
\hline
\end{tabular}

Table 11.7 Origin of improved varieties of cowpea by gender according to Chi square

\begin{tabular}{l|l|l|l|l|l|l}
\hline \multirow{2}{*}{ Origin of improved cowpea seed } & \multicolumn{3}{|l|}{ Komcallé variety } & \multicolumn{3}{l}{ Tiligré variety } \\
\cline { 2 - 4 } & Male & Female & Chi square & Male & Female & Chi square \\
\hline State/government & 42 & 61 & $11.6319^{* * *}$ & 20 & 10 & $8.1174^{* *}$ \\
\hline NGO/project & 15 & 13 & & 10 & 12 & \\
\hline INERA/TLIII & 23 & 9 & & 11 & 20 & \\
\cline { 1 - 3 } Savings & 0 & 2 & & 2 & 0 & \\
\hline
\end{tabular}

NS not significant

${ }^{* *}$ significant at $5 \% ;{ }^{* * *}$ significant at $1 \%$

source of varieties is INERA/TL III where $19.40 \%$ of producers used INERA/TL III varieties mainly through demo tests. $28.80 \%$ of men obtained their supplies through INERA/TL III as well as $10.60 \%$ of women. NGOs/Projects are the third supplier of the improved variety Komcallé; indeed $19.40 \%$ of the producers' source of the variety Komcallé was through NGOs/Projects. $18.80 \%$ of the men obtained seed supplies from the NGOs/Project and $15.30 \%$ of women for the variety Komcalle. For Tiligre, $35.30 \%$ of cowpea farmers received seed from the Government against $25.90 \%$ from NGOs/Projects and $36.50 \%$ from INERA/TLIII. $46.50 \%$ of men bought from the State against $23.8 \%$ for women. $47.60 \%$ of women purchased from INERA/TL III against $25.60 \%$ of men. $36.50 \%$ of the producers acquired the variety Tiligré through INERA/TL III, while $35.30 \%$ of the women got their supplies from the extension services. $46.50 \%$ of the men bought from the extension services, while $47.60 \%$ of the women got their supply through INERA/TL III (Table 11.6).

Chi square tests show that there is a significant difference between men and women for seed origin. For the Komcalle variety the significance is $1 \%$, while for the Tiligré variety the significance is $5 \%$ (Table 11.7).

\subsection{Gender Factors Influence on Access to Seeds of Improved Varieties in Gourcy}

A focus group survey was conducted to investigate factors influencing access to improved cowpea varieties, freedom of mobility, the right to buy improved seeds, access to transportation, land, extension services, information about and management of family revenue. The results are explained below and summarized in Table 11.8. 
Table 11.8 Gender factors affecting access to improved seeds at Gourcy

\begin{tabular}{|c|c|c|c|c|}
\hline Gender factors & & Men & Women & $\begin{array}{l}\text { Chi } \\
\text { square }\end{array}$ \\
\hline \multirow[t]{2}{*}{ Freedom of mobility } & Yes & 78 & 66 & \multirow[t]{2}{*}{$3.5714^{*}$} \\
\hline & No & 22 & 34 & \\
\hline \multirow{2}{*}{$\begin{array}{l}\text { Woman's right to buy improved seeds without her } \\
\text { husband's advice }\end{array}$} & Yes & 71 & 56 & \multirow[t]{2}{*}{$4.8538^{* *}$} \\
\hline & No & 29 & 44 & \\
\hline \multirow{4}{*}{$\begin{array}{l}\text { Decision-making on the choice of the cowpea } \\
\text { variety to be produced in the family }\end{array}$} & Woman & 5 & 7 & \multirow[t]{4}{*}{$1.4690 \mathrm{NS}$} \\
\hline & Man & 42 & 44 & \\
\hline & Jointly & 52 & 49 & \\
\hline & Others & 1 & 0 & \\
\hline \multirow[t]{4}{*}{ Main means of transportation } & Foot & 11 & 39 & \multirow[t]{4}{*}{$43.6544^{* * *}$} \\
\hline & Bicycle & 51 & 57 & \\
\hline & Motorcycle & 35 & 4 & \\
\hline & Others & 3 & 0 & \\
\hline \multirow[t]{2}{*}{ Possession of radio or television set } & Yes & 87 & 51 & \multirow[t]{2}{*}{$30.2945^{* * *}$} \\
\hline & No & 13 & 49 & \\
\hline \multirow[t]{3}{*}{ Management of the revenue from cowpea sales } & Husband & 62 & 29 & \multirow[t]{3}{*}{$37.0903^{* * *}$} \\
\hline & Woman & 3 & 33 & \\
\hline & Jointly & 35 & 38 & \\
\hline \multirow{2}{*}{$\begin{array}{l}\text { Can a woman contact an extension agent without } \\
\text { the consent of her husband? }\end{array}$} & Yes & 73 & 61 & \multirow[t]{2}{*}{$3.2564^{*}$} \\
\hline & No & 27 & 39 & \\
\hline \multirow{2}{*}{$\begin{array}{l}\text { Does the woman have enough time to take care of } \\
\text { her individual field? }\end{array}$} & Yes & 92 & 70 & \multirow[t]{2}{*}{$15.7245^{* * *}$} \\
\hline & No & 8 & 30 & \\
\hline \multirow{2}{*}{$\begin{array}{l}\text { Does access to women's land limit access to } \\
\text { cowpea improved seeds? }\end{array}$} & Yes & 83 & 64 & \multirow[t]{2}{*}{$9.2671^{* * *}$} \\
\hline & No & 17 & 36 & \\
\hline \multirow{2}{*}{$\begin{array}{l}\text { Is the land used by women adapted to cowpea } \\
\text { cultivation? }\end{array}$} & Yes & 93 & 82 & \multirow[t]{2}{*}{$5.5314^{* *}$} \\
\hline & No & 7 & 18 & \\
\hline
\end{tabular}

**** significant at $1 \%$; ${ }^{* *}$ significant at $5 \%$; ${ }^{*}$ significant at $10 \%$

\subsection{Liberty of Mobility}

The Chi square test shows that there is a significant difference between men and women compared to mobility at the $10 \%$ threshold. The focus group interviews actually confirmed these results in that the woman cannot move like the man. Her husband's permission is needed to avoid misunderstandings between the couple (Table 11.8).

\subsection{Women's Right to Buy Improved Seed Without Their Husband's Consent}

The results of the Chi square test show that there is a significant difference between the perception of the man and the woman on the right of a woman to buy improved varieties of cowpea without the advice of her husband. This is significant at the $5 \%$ 
level. Focus group interviews showed that the woman must first seek her husband's advice before buying the improved cowpea varieties because it is the husband who gives the plot of land to the woman or who helps her to acquire the land. It is the husband who is the head of the family and has the power of decision.

\subsection{Decision-Making About the Choice of Cowpea Variety to Produce in the Family}

This variable is not statistically significant according to the Chi square test. Interviews at the focus group discussion showed that the decision to choose the cowpea variety to be produced varied from household to household. The decision was most often made by the husband; for some cases it is a joint decision. However, in a situation where the man is incapacitated, the woman the responsibility to choose the variety because she is in charge of preparing the meals. A number of characteristics (flavor, energy use for cooking, conservation, ease of transformation, etc.) are taken into account in making the decision.

\subsection{Main Means of Transportation}

The main means of transportation is a variable that is statistically significant at the $1 \%$ level. This means that there is a significant difference between men and women on their main mode of transportation. The means of transport is an important element for transporting products from the field to the home and from the home to the market. The results of the focus group interviews confirmed this difference between men and women. This fact certainly had an impact on access to improved cowpea seeds.

\subsection{Possession of Radio or Television Set}

Possession of a radio or television set can provide access to seed information. The results of the Chi square test show that there is a significant difference between men and women on the possession of a radio or television set at the $1 \%$ threshold. Focus group interviews confirmed this difference.

\subsection{Management of the Revenue from Cowpea Sales}

The management of revenues from the sale of cowpea based on the results of the Chi square test is statistically significant at the $1 \%$ threshold between men and women. This means that there is a significant difference between men and women. The interviews showed that the men who are the heads of families managed the income from the sale of cowpea. Sometimes the husband consults the woman on the management of this income. Management is rarely entrusted to women according to discussion results. 


\subsection{Contacts Between Women and Agricultural Extension Agents}

The results of the Chi square test show that there is a significant difference (10\%) in the responses of men and women on contacts between women and extension agents. The results of the interviews show that women prefer to seek the advice of their husbands before contacting the agriculture officer because this contact can be misinterpreted. A large number of men think that, out of respect for the husband, the wife must inform her husband.

\subsection{Does the Woman Have Enough Time to Take Care of Her Individual Field?}

The Chi square test results showed that there is a significant difference between the responses of men and women at the $1 \%$ level. The results of the focus group discussions show that women are overworked by housework as well as by work in the common field which means that they do not have enough time to properly maintain their individual fields.

\subsection{Does Access to Women's Land Limit Access to Cowpea Improved Seeds?}

The results of the quantitative surveys show that there is a significant difference in perceptions between men and women about women's access to land and access to seeds of improved cowpea in particular and improved seeds in general. This difference is significant at the $1 \%$ level according to the Chi square test results. During the interviews it was noted at the level of the women's group that land granted to women is small. However, men qualified this discrepancy by saying that the problem of land is general and concerns both women and men.

\subsection{Is the Land Used by Women Adapted to Cowpea Cultivation?}

The results of the Chi square tests show that there is a significant difference at the $5 \%$ threshold between the perceptions of men and women on the adaptation of land granted to women for cowpea production. The interviews revealed that the women's group felt that the land they are given is small and less fertile. The men think that there is more arable land and that the problem concerns both men and women.

The results in Table 11.9 show that the age of producers varies by gender. In fact, the average age of men is 47.42 years, while that of women is 44.47 years. In other words, on average, the men in the sample are older than the women by 2.5 years. There is a significant difference at the $10 \%$ threshold for men to be older than the 
women in the sample. The average age for all producers combined is 45.9 years. The number of people per household by gender (household size) is the people who live with the producer and share the same roof.

The experience of the cowpea producer by gender showed that men are more experienced and older in cowpea production in the area. Indeed, men have 16.61 years of experience on average against 14.07 years for women. The average number of years of experience is 13.65 years. There is a significant difference between men and women in terms of experience in cowpea production at the $5 \%$ threshold as shown in Table 11.6.

In terms of area covered by cowpea, the results showed that men exploit larger areas of cowpea regardless of variety than women. In fact the average surface area for men is 1.075 ha and women is 0.81 ha. The areas under improved varieties of cowpea are always greater for men $(0.74 \mathrm{ha})$ than for women $(0.5 \mathrm{ha})$. There is a highly significant difference at the $1 \%$ level as shown in Table 11.6.

\section{Distance between Improved Cowpea Variety Selling Point and the Closest House} by Gender The results show that the average distance between the place of sale and distribution of improved varieties is $16.7435 \mathrm{~km}$ for any class of producers. However, women travel shorter distances to acquire improved cowpea seeds. This distance would be $14.93 \mathrm{~km}$ for women, while men travel an average of $18.557 \mathrm{~km}$. Note that this distance is not statistically significant.

Quantity of Komcallé Seeds per Producer by Gender Of the improved varieties of cowpea, Komcallé is the most available. The average quantities used per producer is $8.86 \mathrm{~kg}$. The average amount used by men $(9.89 \mathrm{~kg})$ is greater than the amount used by women $(7.92 \mathrm{~kg})$ and this difference in quantity is statistically significant between men and women according to the results in Table 11.6.

Quantity of Tiligré Seed per Producer by Gender The second most available variety is Tiligré. The average quantity by farmers is $4.212 \mathrm{~kg}$. This quantity is higher for men $(4.795 \mathrm{~kg})$ as compared to women $(3.634 \mathrm{~kg})$. However, there is no statistical difference in quantity between the two groups as shown in Table 11.6.

Quantity of Cowpea Produced and Sold by Gender The quantity of cowpea produced and sold was estimated using $100 \mathrm{~kg}$ bags during the survey. The overall quantity of cowpea produced on average by men is $5.36 \mathrm{bags}$ of $100 \mathrm{~kg}$ and by women 3.567 bags of $100 \mathrm{~kg}$. The average quantity per producer regardless of sex was 4.463 bags of $100 \mathrm{~kg}$. The analysis showed a significant difference between men and women in terms of production. The quantity sold also varied by gender. Men sold, on average, 3.8675 bags of $100 \mathrm{~kg}$ of cowpea, while women sold 2.53325 bags of $100 \mathrm{~kg}$. The quantity sold, on average, was 3.2 bags of $100 \mathrm{~kg}$ of cowpea as a whole, regardless of variety and sex. 
Capacity for Buying Seeds if all Improved Cowpea Varieties are available by Gender The potential purchase of improved variety seeds is on average $8.64 \mathrm{~kg}$. The potential capacity of purchasing seeds varies by sex and is, respectively, $6.76 \mathrm{~kg}$ for women and $10.52 \mathrm{~kg}$ for men. The analysis showed a difference between men and women that is statistically significant (Table 11.9).

This study conducted in five communes of Gourcy using the mixed method revealed that there is no significant difference between women and men for accessing improved cowpea varieties. The main modes of acquisition of improved cowpea varieties in this zone are purchase $(38.80 \%)$ and donation $(32 \%)$. Women are the main beneficiaries of donations (48.2\% of women vs. $15 \%$ of men). TLIII Multi

Table 11.9 Socioeconomic characteristics of farmers surveyed by gender

\begin{tabular}{|c|c|c|c|c|c|c|}
\hline Variables & Male & Female & $\begin{array}{l}\text { Average of } \\
\text { males and } \\
\text { females }\end{array}$ & Difference & T-stat & P-value \\
\hline Age (years) & 47.4 & 44.5 & 45.9 & 2.95 & 1.9594 & $0.05115^{*}$ \\
\hline $\begin{array}{l}\text { Number of years of } \\
\text { experience in cowpea } \\
\text { production }\end{array}$ & 16.6 & 14.1 & 15.3 & 2.54 & 2.0749 & $0.0393^{* *}$ \\
\hline $\begin{array}{l}\text { Number of people per } \\
\text { household }\end{array}$ & 14.4 & 12.9 & 13.7 & 1.56 & 1.0226 & 0.3077 \\
\hline Total area owned (ha) & 5.77 & 2.64 & 4.20 & 3.13 & 7.144 & $0.0000^{* * *}$ \\
\hline Total area planted (ha) & 3.56 & 1.70 & 2.63 & 1.86 & 8.534 & $0.0000^{* * *}$ \\
\hline $\begin{array}{l}\text { Area covered by cowpea } \\
\text { (ha) }\end{array}$ & 1.08 & 0.81 & 0.94 & 0.26 & 2.5954 & $0.0102^{* *}$ \\
\hline $\begin{array}{l}\text { Area covered by } \\
\text { improved cowpea (ha) }\end{array}$ & 0.74 & 0.50 & 0.62 & 0.24 & 3.0077 & $0.0030^{* * *}$ \\
\hline $\begin{array}{l}\text { Distance between } \\
\text { improved cowpea } \\
\text { variety selling point and } \\
\text { the closest house }(\mathrm{km})\end{array}$ & 18.6 & 14.9 & 16.7 & 3.63 & 1.3447 & $0.1802 \mathrm{NS}$ \\
\hline $\begin{array}{l}\text { Quantity of Komcallé } \\
\text { seed per producer }(\mathrm{kg})\end{array}$ & 9.89 & 7.92 & 8.86 & 1.96 & 1.6092 & $0.1096 \mathrm{NS}$ \\
\hline $\begin{array}{l}\text { Quantity of Tiligré seed } \\
\text { per producer }(\mathrm{kg})\end{array}$ & 4.80 & 3.63 & 4.21 & 1.14 & 0.8597 & $0.3926 \mathrm{NS}$ \\
\hline $\begin{array}{l}\text { Quantity of cowpea } \\
\text { produced (bags of } 100 \\
\mathrm{~kg} \text { ) }\end{array}$ & 5.36 & 3.57 & 4.46 & 1.79 & 3.2641 & $0.0013^{* * *}$ \\
\hline $\begin{array}{l}\text { Quantity of cowpea sold } \\
\text { (bags of } 100 \mathrm{~kg} \text { ) }\end{array}$ & 3.87 & 2.53 & 3.20 & 1.34 & 2.6067 & $0.0098^{* * * *}$ \\
\hline $\begin{array}{l}\text { Value of cowpea sales in } \\
\text { FCFA }\end{array}$ & 127,349 & 73742 & 100545.5 & 53607 & 2.0085 & $0.0459^{* *}$ \\
\hline $\begin{array}{l}\text { Capacity for buying } \\
\text { seed if all improved } \\
\text { cowpea varieties are } \\
\text { available by gender }\end{array}$ & 10.52 & 6.76 & 8.64 & 3.76 & 3.3712 & $0.0009^{* * * *}$ \\
\hline
\end{tabular}

${ }^{* * *}$ significant at $1 \%$; ${ }^{* *}$ significant at $5 \%$; "significant at $10 \%$; NS not significant 
stakeholders' platform (MSP) method served as the second way to access cowpea seeds as a direct contribution from demos and local seed production. Gender factors affecting access to improved varieties of cowpea are freedom of movement, the women's right to buy improved seeds without her husband's advice, the main means of transportation, the possession of radio or television set, the management of the revenue from cowpea sales, the obligation for a woman to obtain the consent of her husband to contacting an extension agent, the lack of enough time for women to take care of their individual fields, and so on.

\subsection{Reflections on the Process}

\subsubsection{Areas to Focus on in the Future}

The main issues the platform has not been able to handle so far should be given due attention by future interventions (e.g., get back again on how to enhance sustainability of the platforms).

- We should think again our way of supporting these platforms so they can be less dependent on the support that the project is giving. Even if some few people can stand alone, most of the producers are dependent on the project and do not really know the opportunities that these platforms offer.

- In some of the platforms, communication between the different members of the platform was a serious issue and this shall be addressed to make the platform perform better.

\subsection{Lessons Learned}

Highlights of Key Achievements

- Made the newly released varieties of cowpeas more popular.

- Increased the adoption rate of improved cowpea varieties.

- Demo trials were very successful in introducing new varieties to the community.

- Provided opportunities to highlight success stories while identifying successful producers.

Three major lessons learned

1. A great opportunity is offered to all the actors working on the platform to make profit from their activity.

2. Land access to women is a challenging issue that needs addressing.

3. Most members of the platform are too dependent on the project. This is not good for sustainability. 


\section{References}

Batieno TBJ (2014) Breeding for drought tolerance in cowpea [Vigna unguiculata (L.) Walp.] using marker assisted backcrossing. University of Ghana, Accra

Tignegre JBDLS (2010) Genetic study of cowpea (Vigna unguiculata (L.) Walp.) resistance to Striga gesnerioides (Willd.) Vatke in Burkina Faso. University of KwaZulu-Natal, 131 Durban/ South Africa

Verdcourt B (1970) Studies of the Leguminosae-Papilionoideae for 'Flora of Tropical East Africa': IV. Kew Bull 24(3):507-569

Open Access This chapter is licensed under the terms of the Creative Commons Attribution 4.0 International License (http://creativecommons.org/licenses/by/4.0/), which permits use, sharing, adaptation, distribution and reproduction in any medium or format, as long as you give appropriate credit to the original author(s) and the source, provide a link to the Creative Commons license and indicate if changes were made.

The images or other third party material in this chapter are included in the chapter's Creative Commons license, unless indicated otherwise in a credit line to the material. If material is not included in the chapter's Creative Commons license and your intended use is not permitted by statutory regulation or exceeds the permitted use, you will need to obtain permission directly from the copyright holder.

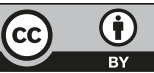

